\title{
Structural changes in livestock production: the case northeastern Montenegro
}

\author{
Goran Rajović $^{1, *}$, Jelisavka Bulatović ${ }^{2, \star *}$ \\ ${ }^{1}$ Street Vojvode Stepe 252, Belgrade, Serbia \\ Phone: 0038161/19-24-850 \\ ${ }^{2}$ College of Textile Design, Technology and Management, \\ Street Starine Novaka 20, Belgrade, Serbia \\ Phone: 003861/ 3082651 \\ ${ }^{*, \star * E-m a i l ~ a d d r e s s: ~ d k g o r a n . r a j o v i c @ g m a i l . c o m ~, ~ j e l i s a v k a . b u l a t o v i ~}$
}

\section{ABSTRACT}

The production structure of agriculture northeastern $\mathrm{N}$ negro vestock production has a very important role, because without a stable and dey ropo livestoc bduction has neither developed agriculture. Therefore, in this paper, shows th change in the nun,oer of livestock by type and category. Fluctuations in the number of cattle in t period 1964-2005, primarily the result of economic factors, such as reduced local and regional rkets, low purchasing power, transition, privatization, lack of long-term development strategy ivect $\mathrm{k}$, technological and technical unwillingness processing facilities, primary pro on disorgantzation, poor farmers and processors association, insufficient and slow recovery rad 1 co tion of cattle. Applying the method of alternating splitter Systems 6/6 in 1964, we ha ound 1 northeastern Montenegro, type with a dominant share of sheep and cattle s $\left.\mathrm{O}_{5} \mathrm{G}_{1}\right)$, with equal participation of sheep a d catt $\left(\mathrm{O}_{3} \mathrm{G}_{3}\right)$. aging by the number and categories of livestock by type, production volume, a $n$ as the indidators, livestock production in the region, mainly serves to meet the needs of arwhou old. A sinaller part of are intended market. To mention the problems were solved in appropria nanner, it is necessary to adopt appropriate strategies in livestock development ith proposed easures, that has to be long term, because only in this way can stop the decline in he num of cattle to provide the increase livestock production and improve the quality of live sock products.

Keywords: No stern M ntenegro; livestock breeding; production; incentives

1. IN UDUCAON

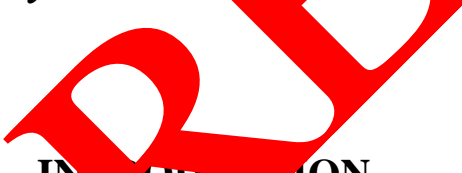

Nortb astern Montenegro is a geographical unit which comprises $10.8 \%$ of the total area of Montenegro (13.812 $\left.\mathrm{km}^{2}\right)$, that is, living in the territory, $8.12 \%$ of the population compared to the total population of Montenegro in 2003 (673.094). Territory includes three municipalities: Plav, Andrijevica and Berane, with an area of $1.486 \mathrm{~km}^{2}$, which is by the census of 2003 year, 54.658 people lived or $36.8 \mathrm{in} / \mathrm{km}^{2}$ (Rajović and Bulatović, 2013a).

Types of agricultural land and its qualitative characteristics are favorable for the development of agriculture northeastern Montenegro. However, survey analysis that follows shows that livestock production is not in conformity with all available natural and social 
conditions. Discrepancy between available resources and modern livestock production is determined by the global economic policy, tradition, demographics, economic structure and market (Rajović, 2007a). Specifically, the northeastern territory of Montenegro, insufficient attention was paid to the problems of agricultural development, especially the choice of the optimal structure of production. Also, the present method of management (small plots, tillage outdated, uncoordinated structure of production), is a function of agricultural development (Rajović, 2009a). Greater appreciation of agriculture as a primary activity, which can be exploited comparative advantages of the region.

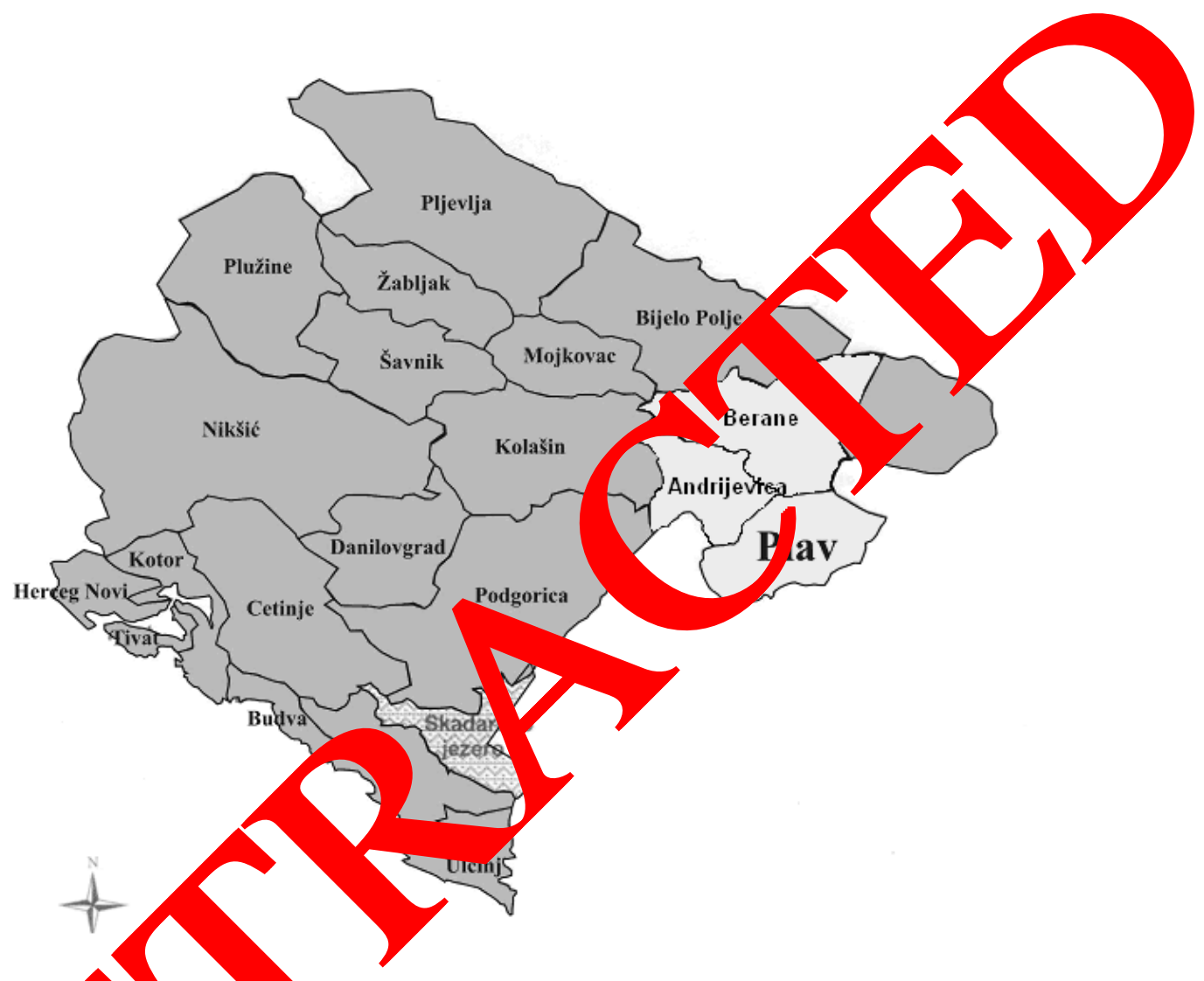

Figure 1. the ge smphical pos of the municipality Berane, Andrijevica and Plav (Northeastern Montenegre on th map of Mo renegro. (Source: Regional Business Centre Berane (2004a,b),

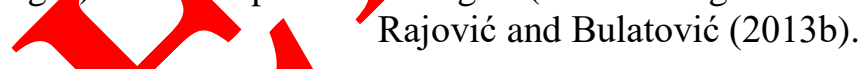

The cle of 0 momic activities can best be initiated and run if the first approach to inve o delopment of agriculture as a sector because it has the most massive econon resources. These resources need to intelligently and rationally (Rajović, 2012 a). Livestock Auction, as an integral and one of the most important parts of agricultural production and the area with the fastest turnover of capital in agriculture, directly depend on all the parameters that influence the market, either at the macro or micro level (Smiljanić et al, 2006) [30].

Animal Husbandry influences on the development of crop production, because about three-quarters of the production is spent on animal nutrition, noting that much of the biomass and the man would not be able to use it in another way. From livestock as a by-product of crop production returns manure, very important tool for maintaining are structure of the productive capacity of land. The manufacturing process is considered to be the toughest 
livestock in agriculture, because it takes constant throughout the year, regardless of season and weather conditions (Nikolić et al, 2006). The results of this survey were used to work the authors consider structural changes and livestock production due to the application of alternate methods splitter in the system 6/6, allocate livestock use directions. This article refers only to the portion of the truth of important issues related to livestock production northeastern Montenegro, while other studies, such as those that indicate the typological characteristics of agriculture: current owner and socio-organizational-technical, of great importance from the point of view of scientific knowledge for the proper routing of all social actions and measures of agricultural policy. Of course, they are not the subject of this-mener.

\section{RESEARCH METHODOLOGY}

This paper has the following objectives. First of all, to determir are st tural anges in livestock production in the period 1964-2005. The next goal is th the deve pment of incentives. Finally, the research goal, we separate directions livestock e. T e research methodology is primarily based on an analysis of existing ag reographi citerature and statistical data provided by the Statistical Office of Mo teneg The literature include: agricultural monographs, proceedings, books and static nes. Nere stu and written sources on the internet. In the context of agro-geographic sty $y$ of agriculture, $y$ e apply the method to a system of alternating dividers 6/6, developed at e Institute f Geography of the Polish Academy of Sciences (Kostrovicki, 1969 and Kostro ki, 1970) This method determines the orientation of the agricultural territory studied (Jaćim 10 16). The literature review and the terms under the agricultural structure a nedure for applying the method, "kolejnih ilorazow" (alternate splitter), and provides $\mathrm{T}$, $\mathrm{Zk}^{*}$ - 1978). The scientific explanation of the concepts in this study, we annlied tw methods are used: analytic and synthetic. Analytical methods are conside ed ne of e dimensions of the research topic, and a synthetic whole, the intercon ions between ne case and suggested measures that derive there from (Rajović and B

\section{ANALYSIS A DISC}

Anima usban is the second agricultural activity which is closely adjacent to crop production. Th ore, are evelopment of agricultural activity, determined by the quality and product bio sr m natural grasslands, on the one hand and the production of fodder frop arabl and on other side? Moreover, the nature and extent of livestock production is grea inf (Rajov 2011a).

An Husbandry northeastern Montenegro has long rested on the use of natural grassland (cattle, sheep) and forest area (pig). For grazing cattle and sheep were used mountain pastures, mountain meadows and pastures and meadows of the valley. Mountain meadows and pastures and meadows of the valley are typically used as a grazing area after cutting the first cut (June - July). During the winter period for livestock feed in addition to hay, hazelnuts and acorns, on a smaller scale was used and fodder from arable land (oats, barley, rye, corn ....) (Rajović, 2012b).

Statistics on the movement of livestock and agricultural production is difficult to obtain because of a lack of proper statistical material. In other words, this means that the statistics do 
not pay enough attention to the condition of livestock and livestock production, and without such materials is impossible to give an overall view of agricultural production. Therefore, in view of the livestock we use data from the dairies and slaughterhouses in Berane and data through surveys milk and meat (Rajović, 2007b) in the region, which will be processed according to the data of the Statistical Office of Montenegro (1965 and 2006).

Before proceeding to view the present state of livestock in northeastern Montenegro, it is important to point out that farming is a significant potential for the development of agriculture and economic development of the region, but is underdeveloped compared to the natural resources and the demands of intensive agricultural production( Rajović, 2009 b. Doiović, 2011b).

Quantity movement of livestock in certain livestock sectors was differe An analy of the number of livestock in each category in northeastern Montenegro ip the $\mathrm{A} 196$ 2005 year indicates a reduction in cattle (3.915 animals), sheep $(26.50 \%$, pros ( 9 , hor,es (3.020). Thus, in the period 1994 - 2005 the number of cattle in the re on, flu yated on the tendency to reduce the number of cattle, sheep, pigs, horses. "Oscisti cattle ring this period, as a result of economic factors that have influenced the ievelopm of crain cattle industries, such as extensive character, throat, low product w residual nod of forest ..."(Jaćimović, 1978). Number of cattle by the National tatist Office of Montenegro (2006), was reduced in the period 1964 - 2005 for 3.91 am als. Tho mber of sheep in that period is drastically varied, depending on the numb $r$ of cattle due to market disruption, or falling prices of mutton. Specifically, during 1964 - 05, there w/s a reduction in the number of sheep for 26.500 pieces. The total number of pigs lso redured by 972 pieces. Given that official statistics do not provide data on the mumber of 1964, will use the data of the Statistical Office of Montenegro from 1995 umber of poultry in 1994. In the period of 1994-2005, the number of birds in the re on itan reduced by 33.493 units. This reduction in poultry can only be exnlained, il reased consumption of poultry meat. This is understandable, given at a much nigh price: $\mathrm{p} \mathrm{rk}$, beef and mutton. Thus poultry, gaining a greater role in are local econo

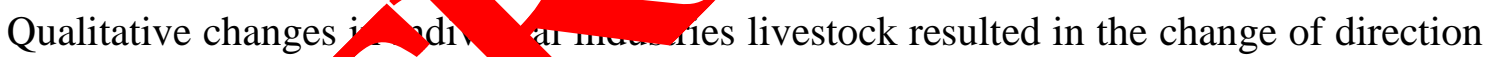
livestock. Applying th method a ternating splitter in the system $6 / 6$, we found in northeastern Monten gro 1964, fol wing the direction of livestock use: $\mathbf{O}_{5} \mathbf{G}_{\mathbf{1}}$ Type the dominant share heep. cattle share (The variables and their symbols used in the formula: G-Car 1 e, S Pig, O-S, S). So, the guy with the dominant share of sheep and cattle share in 196 ear, g ually transformed into a type of equal participation of sheep and cattle in 2005.

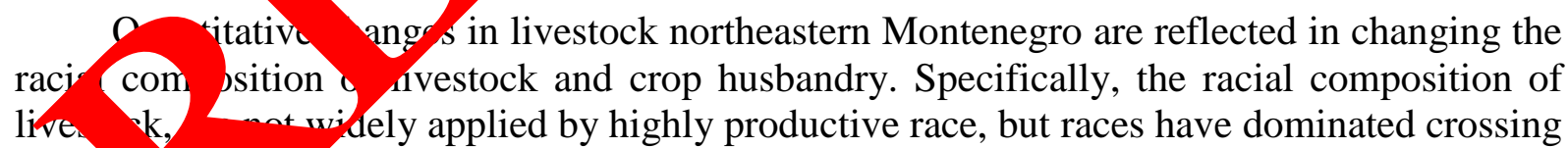
of don ic and foreign species. In livestock farming are region, dominated by sheep and cattle. On $\%$ of agricultural land (the total acreage of the region is 67.379 ha), 59.2 comes sheep, 27.5 cattle, 3.5 pigs, 3.2 horses, which is certainly not enough in relation to the potential opportunities in the region.

Sheep production is by the number of cattle heads most important activity in the region. Based on the development of the livestock sector, make natural grasslands and pastures (Rajovic 2004). Is the development of sheep and determined the need for wool in their homes.

Reducing is total number of sheep. In the period 1964 - 2005 the number of sheep has decreased from 68.534 to 39.877 animals. This can be explained by the lack of labor, poor economic conditions, extensive ways herding, alienation lambs for slaughter with a small 
measure of living up to $15 \mathrm{~kg}$ which reflects negatively on the profitability of production, low purchase price of lambs, sheep, wool and hides (Tomić 1984). The period reduced the number of sheep on one hectare of agricultural land. Number of sheep per unit of agricultural land (the total acreage of the region in 1964, was $70.478 \mathrm{ha}$ ), decreased from 0.94 head/ha in 1964 to $0.59 \mathrm{head} / \mathrm{ha}$ in 2005 . The racial composition of livestock is very unfavorable. The racial composition of the two types of sheep predominates: mining and mountain sheep. Sheep breeding is usually related to their own needs, so that the market surplus estimates. Most of the surpluses of the livestock sector, traditionally, are sold in markets or sold to customers.

According to survey estimates in 2005, the region has produced about 324 tons a sheep meat. ILO also estimates indicate that in 2005, the sheep milk production was a it 2.042.638 1, with an average milk production of 50 liters per dairy sheep $f$ ing the ye Most of the sheep milk is processed into households, separately or togethe with w's mi the cheeses of varying quality. Wool production in 2005 was about $36 \mathrm{t}$ s. Averas ield of wool per sheep are very low at around $1.2 \mathrm{~kg}$. Most of the wool $\mathrm{p}$ tuced used their homes; much less part is placed on the market.

Table 1. Number of livestock in the region in

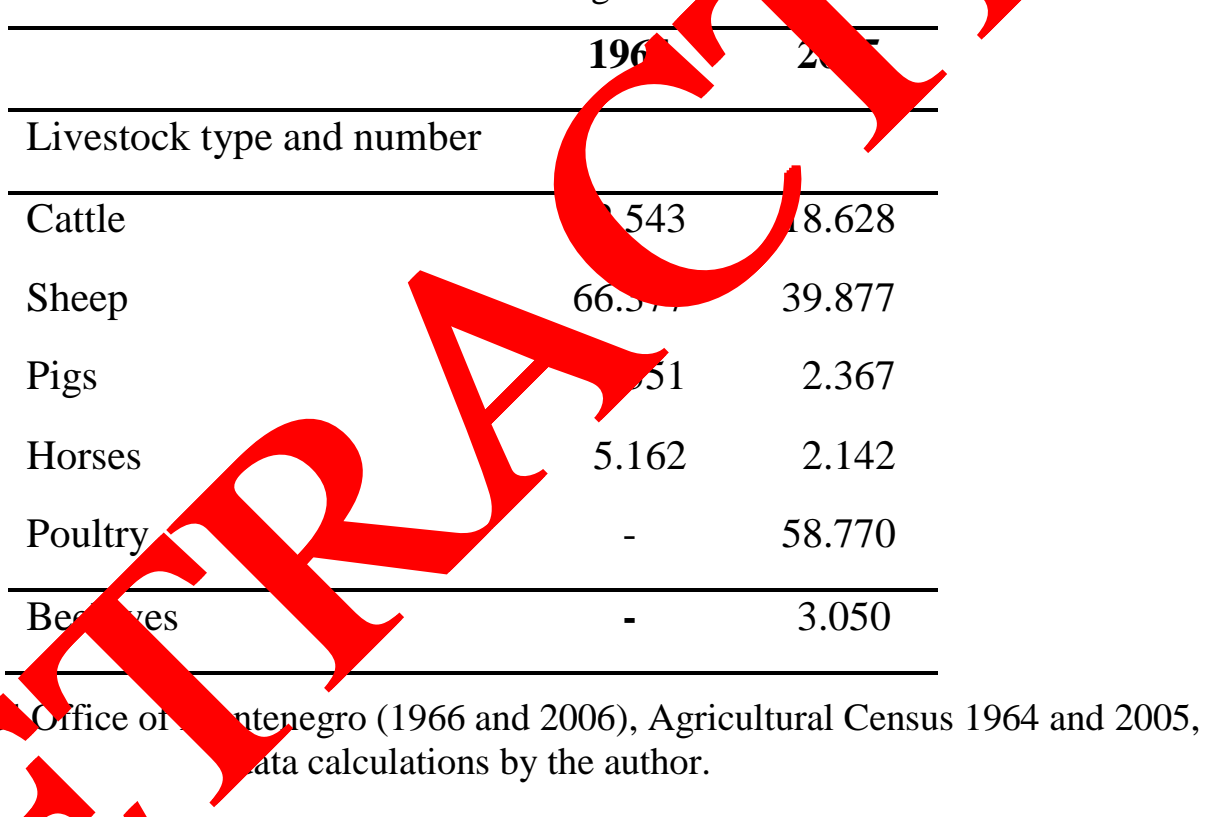

Source: Statisti Cifice on ntenegro (1966 and 2006), Agricultural Census 1964 and 2005, ata calculations by the author.

are umbe of cattle ecreased by 3.915 cattle and 22.543 in 1964 with to 18.628 animals in
200 sab
to obta

The Yal composition dominated: Bush's domestic cattle and crosses of domestic drilling and spotted cattle. Number of head of cattle on one hectare of agricultural land declined from 0.32 in 1964 to 0.28 in 2005. "The spatial distribution of cattle showed a correlation with those surfaces that are constantly a greater share of green crops in the agricultural structure, i.e., with meadows and pastures, and also with the areas where a lot of fodder crops grown" (Jaćimović, 1978). Milk production in 2005 was about 1.722 .5801 with an average milk production of 1301 per dairy cow. Low milk yield of cows is a consequence of racial composition and inadequate nutrition. According to survey estimates for 2005 in the region has produced about 620 tons of beef. 
Poultry rising is an important livestock activity. The total number of head of poultry in the region in 2005 amounted to 58.770 heads. From the largest poultry: homemade chicken, homemade matzo and Styria, partridge Italian, Leghorn, "radajland".... Other poultry (PACT, geese, turkeys ...), is symbolically represented. According to survey estimates for 2005, egg production was around 100 eggs per hen coccid.

Other types of livestock are not in harmony with the natural capabilities of the region. Number of pigs in the period 1964 the year 2005 was reduced to 972 animals or the throat in 4.551 in 1964 to 2.367 animals in 2005 (Table 1). The racial composition of the pig nuvails: Domestic white meaty pig, Yorkshire, Landrace, Dutch and Swedish. Growing plgs us y related to their own needs, with little production for the market.

Horse breeding cattle industries are which is significantly lost in economi portanc With the advent of mechanization importance of horses in agricultural product in ne region, the region with a smaller inclination is marginalized. Somethi great impor cee in agriculture, horses were kept in the hill - mountain rim region, wh of $\mathrm{m}$. hinery is limited due to the considerable slope. Number of head of horses in the pen 1964-2005 was reduced to 3.020 animals, respectively, with 5.162 cows in 142 (Tab ). The racial composition of the most dominant horse horses mounta fus io because they are best adapted to the hilly - mountainous areas and poorer con mus for fee

Beekeeping is an activity that livestock natural eatures of the reg.on, is not nearly used. The total number of beehives in the region in 2005 mounted to 3.050 pieces. According to survey estimates for 2005 , produced about 6.1 tons 0 oney. Tot 1 production and production per hive torn and is caused by the climate apd quality 0

Research results lead us to conclu the state of livestock in northeastern Montenegro, may be assessed as unfavorab e, fan the number of animals constantly decreasing. Along with the decline in the i mber of cattle, there was a decline in the production itself. Problems in ag cur that the region is facing years, not well resolved and therefore animal production $\mathrm{f}$

To mention the prob' on sorven an appropriate manner, it is necessary to adopt an appropriate strategy ith the pro ed measures, which must be long term since only in this way can you ens progres in livestock production. Proposed strategy and accompanying me un es ned to stop the decline in the number of first animals provide increased live ock production and improve the quality of livestock products. This is especially in rtant the export of which depends largely on livestock development in the region in the ftu (Rajoy and Bulatović, $2013 \mathrm{c}$ ).

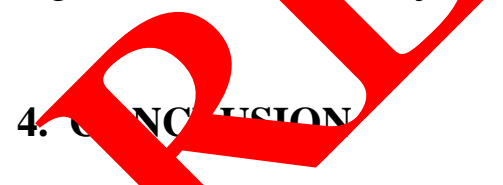

Ou arch records, based on similar research and Kljajić, Arsić and Savić (2011), emphasized. in the foreground, several important conclusions:

1. Stop drop and reduce the number of head of cattle. The region has a very favorable climate for intensive livestock production. Large areas of pasture are very big potential. Land holdings are fragmented, so in this situation, the land under utilized. Small farms in the region have a limited capacity of livestock production, due to the limited production of livestock fodder. Except valley Berane, Andrijevica, Polimlja and Plav-Gusinje, other landscapes of the region, especially the highlands, have very poor infrastructure, no control of water quality (which is used in livestock production), and is the technology 
obsolete ( Rajović and Bulatović, 2013 d). Ways to overcome and solve these problems, there is, first of all, the agglomeration and education company. It is necessary, therefore, to stimulate rural development in order to reduce the differences between city and country, through financial assistance for union households, provision of technical documentation farms which began to livestock production.

2. Considering that food is one of the most important factors contemporary par genetic livestock productions, it is necessary to provide the required amount of feed, forage and concentrates. In this way it provides not only a higher animal production, but thus better quality of livestock products. Animal husbandry in the region does not have the nomssary genetic basis, and will need the appropriate genetic-selectable measures in prova to allow for greater production potential. In terms of the development of ge ic resourc priority should be given to strengthening the selection and advisory sarvic The ma problem in livestock production in the region is the lack of skille labor, an hat ne problem is even bigger, unfavorable age structure and the produce In re time the region in addition to the standard methods of selection in anim ho dry, an methods used in molecular genetics, which is based primarily on th identific of genes, that are appropriate for specific production traits, then, is a io improving production potential of certain breeds of livestock.

3. The introduction of new technologies in animal/usondry in Kegion, they would increase the efficiency and competitiveness in t e market. Primar/production is largely dependent on local resources. On the other hand ecord prodycer dependence on imports, especially when it comes to procuring the nec ry equip nent. One possible solution would be to strengthen domestic production and co with those manufacturers of equipment and machinery, which are ne for the production of livestock and fodder production. Thus, on the one hand, the i pre $/$ of livestock production and ensure greater export of livestock products, on other hand, with the support of the state, through incentives, meet the canc ls of the modern market by the producers themselves.

4. It is essential to the region, vorir private arming, but market-oriented. In other words, market-oriented produc ne ofom to the association, the rational use of available resources in livesto Interestit. association of producers and processors is one of the weak points in th sy of lives ck production in the region. One gets the impression that the manu a curers selves do not know enough about your market on the one hand, and $q$ the other in the gion and that there are no functional interest groups, to deal with the king p ducers to markets (vertical connection) and interconnection in order to rationalize uction ad better market access. And, due to, procurement of necessary mas, and aus sales of livestock products. In order to achieve these objectives, it nece ary to in ove the laws on cooperatives and citizens' associations.

1, "the role of agriculture and rural areas must be first-rate, as are its potentia main forces of the future development of the region. This requires radically new relationsh ${ }_{1}$ getween society and science to agriculture and the countryside (Rajovic and Bulatović, 2013 e). Instead of the former quartermaster approach in which they viewed as a preventive cheap food manufacturers, must develop new concepts, comprehensive rural development, which will be based on the demographic, natural, economic and socio-cultural resources"(www.proučavanjesela.rs). Responsible role in developing the concept of rural development in the region, which will be based on the natural and socio-economic potential of the village, be sure that there are geographical science, agricultural geography, that their holistic approach to integrate research efforts and results of other scientific disciplines. 


\section{References}

[1] Rajović G., Bulatović J., Russian Journal of Agricultural and Socio - Economic Sciences 1(13) (2013) 66-79, (2013a).

[2] Rajović G., Journal Economics 53(3-4) (2007) 58-67, (2007a).

[3] Rajović G., Journal Industry 37 (4) (2009) 15-27, (2009a).

[4] Rajović G., Journal of Agricultural and Food Science Research 1(1) (2012) (2012 a).

[5] Smiljanić M., Petrović M., Pavlovski Z., Trenkovski S., Radović Č., Situatı production and future development, Biotechnology in Animal Husbar ary XVI Innovations in livestock 16-17 November, Belgrade, 2006, pp. 5-

[6] Regional Business Centre Berane, Profile municipality of Ber Available from: http://www.nasme.me (25.01 2013 a), (200 a).

[7] Regional Business Centre Berane, Profile municipality Available from: http://www.nasme.me (25.01 2013) Vu b).

[8] Rajović G., Bulatović J., Journal of Agriculture ld Sustainability 2(2) (2013) 178-195, (2013b).

[9] Nikolić M., Cvijanović D., Subić J., Developmen animal nusbandry as one of the pillars of rural development, Collected ntific papun $\mathrm{X}$ consulting agronomists, veterinarians and technicians, 12 (3-4) (2) 00 ,

[10] Kostrovicki I., Przeglad Geograficzny X1 (4) (1569) 599-621.

[11] Kostrovicki I., Geographi Polo, ca 18 (1 จg) 93.

[12] Jaćimović B., Proceed os Geography Faculty of Science XXIII (1976) 94-99.

[13] Tyszkiewicz W Pra any struk ury przestrzennej rolnictwa Polski 1950-1970, Prace Geograficzp 1-6 Ig a DZPAN, 1978, pp. 15-54.

[14] Rajović r., Jou al Econo nics 58(2) (2011) 62-72, (2011 a).

[15] Rajović @ "nericar Eurasian Journal of Agricultural \& Environmental Sciences 12 ) $(20$ 155-1571, (2012 b).

[1 Rajoy ć G., Str lctural changes in crop and livestock production in the municipalities ijevica and Plav (1994-2000.godine), Serbiafood, Selected papers, A ble from: http://serbiafood.co.yu (31.05 2008), (2007b).

[17] Statis, acal Office of Montenegro, Census agriculture 1964 year, Podgorica, 1966.

[18] Statistical Office of Montenegro, Census agriculture 1994 year, Podgorica, 1996.

[19] Statistical Office of Montenegro, Census agriculture 2005year, Podgorica, 2006.

[20] Rajović G., Journal Economics 55(6) (2009) 33-44, (2009b).

[21] Rajović G., Annals of the University of Oradea - geography series 21(1) (2011) 105-117, (2011b). 
[22] Rajović G., Geographic basis for the development of the economy of the Upper Polimlja

(PhD thesis), University of Novi Sad, Faculty of Science, Department of Geography, Tourism and Hotel Management, Novi Sad, (2004).

[23] Jaćimović B., Proceedings of the Geographical Institute of the Faculty of Sciences 25 (1978) 47-57.

[24] Tomić P., Proceedings of the Geographical Institute of the Faculty of Science 13 (1984) 11-19.

[25] Rajović G., Bulatović J., Journal of Agriculture and Sustainability 3 (2) (2) 165-18 (2013c).

[26] Kljajić N., Arsić S., Savić M., Livestock as a development oppo ity fo verbia, Available from: http://www.agroekonomija.wordpress.com 0 , 3), (20). [27] Rajović G., Bulatović J., Journal of Studies in Social Sci 2 (2) (2u 135-133,
(2013d).

[28] Rajović G., Bulatović J., Journal of Sustainable Dever.pment Si r. 3(2) (2013) 136-167, (2013 e).

[29] Institute for the Study of the village (Belgrade) bout us, Ay hilable from: http://www.proučavanjesela.rs ( 27.01 2013).

[30] Goran Rajović, Jelisavka Bulatović, In onal Letters of Social and Humanistic Sciences 3 (2013) 10-30.

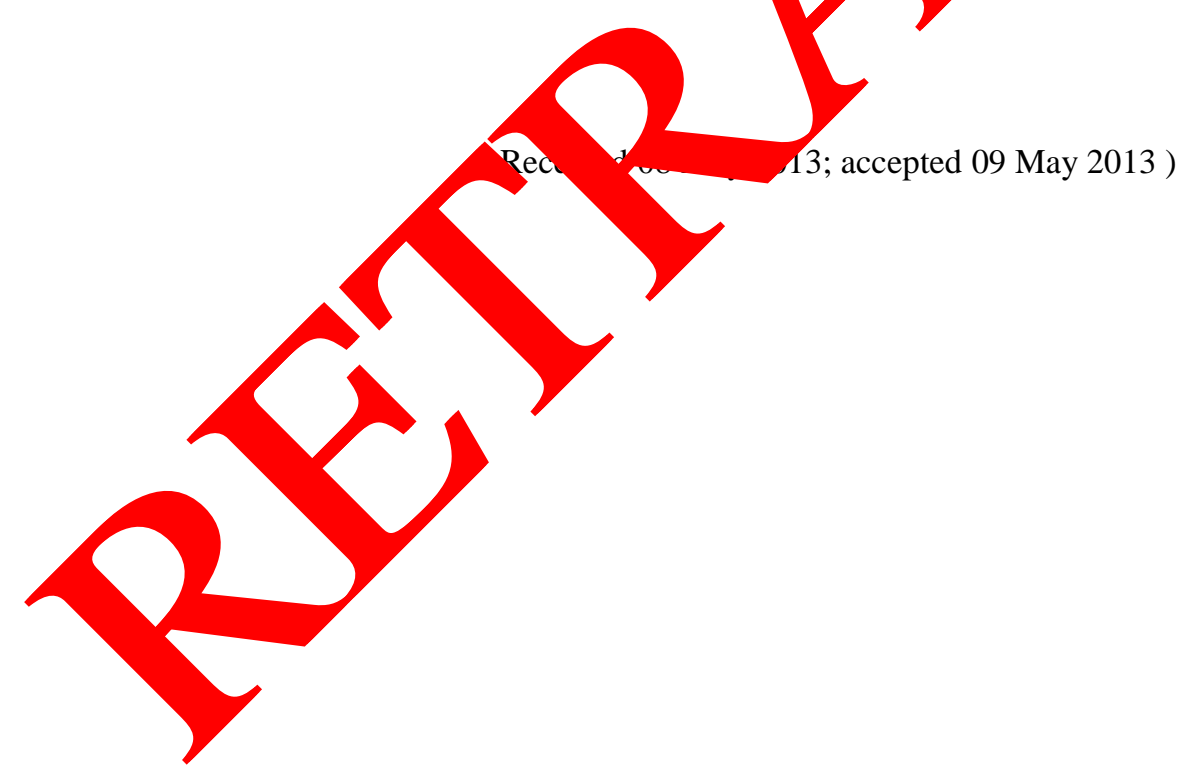

